\title{
Internally mixed soot, sulfates, and organic matter in aerosol particles from Mexico City
}

\author{
K. Adachi ${ }^{1,2}$ and P. R. Buseck ${ }^{1,2}$ \\ ${ }^{1}$ School of Earth and Space Exploration, Arizona State University, Tempe, Arizona, USA \\ ${ }^{2}$ Department of Chemistry and Biochemistry, Arizona State University, Tempe, Arizona, USA \\ Received: 7 April 2008 - Published in Atmos. Chem. Phys. Discuss.: 22 May 2008 \\ Revised: 1 September 2008 - Accepted: 26 Semptember 2008 - Published: 13 November 2008
}

\begin{abstract}
Soot particles, which are aggregated carbonaceous spherules with graphitic structures, are major aerosol constituents that result from burning of fossil fuel, biofuel, and biomass. Their properties commonly change through reaction with other particles or gases, resulting in complex internal mixtures. Using a transmission electron microscope (TEM) for both imaging and chemical analysis, we measured $\sim 8000$ particles (25 samples) with aerodynamic diameters from 0.05 to $0.3 \mu \mathrm{m}$ that were collected in March 2006 from aircraft over Mexico City (MC) and adjacent areas. Most particles are coated, consist of aggregates, or both. For example, almost all analyzed particles contain $\mathrm{S}$ and $70 \%$ also contain $\mathrm{K}$, suggesting coagulation and condensation of sulfates and particles derived from biomass and biofuel burning. In the MC plumes, over half of all particles contained soot coated by organic matter and sulfates. The median value of the soot volume fraction in such coated particles is about $15 \%$. In contrast to the assumptions used in many climate models, the soot particles did not become compact even when coated. Moreover, about $80 \%$ by volume of the particles consisting of organic matter with sulfate also contained soot, indicating the important role of soot in the formation of secondary aerosol particles. Coatings on soot particles can amplify their light absorption, and coagulation with sulfates changes their hygroscopic properties, resulting in shorter lifetimes. Through changes in their optical and hygroscopic properties, internally mixed soot particles have a greater effect on the regional climate of MC than uncoated soot particles.
\end{abstract}

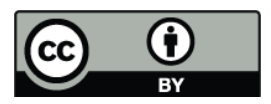

Correspondence to: P. R. Buseck (pbuseck@asu.edu)

\section{Introduction}

Aerosol particles have important influences on Earth's radiative and hydrological balance (Ramanathan et al., 2001), human health (Dockery et al., 1993), and visibility. Knowledge of their contribution to radiative forcing is inadequate (IPCC, 2007). Our study focuses on soot (black carbon) particles that are coated with or attached to organic matter (OM) and sulfate (hereafter we refer to such mixtures as internally mixed particles) collected during the MILAGRO (Megacity Initiative: Local and Global Research Observations) campaign in and near Mexico City (MC) and their implications for global climate. Many developing megacities, such as MC, are located in tropical areas. Their importance will increase through growing economic activity and populations. Many details of the aerosol particles emitted from tropical megacities are not well known, although they have important effects on the troposphere and people living in it.

Soot particles, which are aggregated carbonaceous spherules a few tens of nanometers in diameter and with graphitic structures, are emitted through incomplete combustion of fossil fuel, biofuel, and biomass carbon together with OM. The latter is amorphous carbonaceous material that, in our samples, mainly formed through condensation and coagulation. Soot particles produce a net warming effect in the atmosphere through absorption of sunlight (Chung and Seinfeld, 2002, 2005; Jacobson, 2001; Haywood et al., 1997; Myhre et al., 1998; Penner et al., 1998; Bond and Bergstrom, 2006). Internally mixed soot particles are estimated to be the second most significant component of global warming after $\mathrm{CO}_{2}$ in terms of direct radiative forcing (Jacobson, 2001; Ramanathan and Carmichael, 2008).

Here we focus on particles of soot, OM, and sulfate, with emphasis on internally mixed particles. Climate models assume that aerosol particles are single phases (external

Published by Copernicus Publications on behalf of the European Geosciences Union. 
mixtures), mixtures of different materials (internal mixtures), or both (Jacobson, 2001; Chung and Seinfeld, 2002, 2005; Bond et al., 2006; Bond and Bergstrom, 2006; Takemura et al., 2005; Stier et al., 2007). The external mixing assumption is unrealistic for many atmospheric situations as many, and perhaps most, aerosol particles are internally mixed (e.g., Murphy et al., 2006; Pósfai et al., 1999). Internal mixtures are a better assumption, assuming that appropriate morphological and mixing properties are applied in the models.

Current climate models either assume that soot is concentrically encapsulated by another material (core-shell model) or that a single effective refractive index for the entire mixed particle can be used (Bond et al., 2006). In the latter case, the effective refractive indices are calculated for the mixed materials using various mixing rules (Bond and Bergstrom, 2006; Bond et al., 2006; Stier et al., 2007; Bohren and Huffman, 1983). These calculations need volume ratios of the components of mixed materials in individual particles to determine their optical properties, although these values are commonly not well known but can be determined by using transmission electron microscopy. Also, mixtures of different materials affect hygroscopic properties, i.e., hydrophilic coatings make soot particles hygroscopic. Therefore, a detailed analysis of internally mixed particles is appropriate.

A transmission electron microscope (TEM) is a powerful instrument for determining the morphologies, sizes, and compositions of individual aerosol particles (Abel et al., 2003; Buseck and Pósfai, 1999; Buseck and Schwartz, 2003; Niemi et al., 2006; Johnson et al., 2005; Utsunomiya et al., 2004). Soot is a common constituent of such mixtures, and the TEM can be used to recognize it based on its distinctive morphological features. Moreover, several TEM studies have shown that OM with sulfate coatings on soot particles are widespread (e.g., Chen et al., 2006; Kojima et al., 2005; Pósfai et al., 1999; Li et al., 2003; Okada et al., 2005; Johnson et al., 2005). The single-particle soot photometer (Schwarz et al., 2008) is also good for detecting soot, but because it destroys the particles, one cannot see details of coatings, intergrowths, and aggregations.

Our goal is to characterize the chemical and physical properties of internally mixed soot particles in order to understand their optical properties and coating processes at the individual-particle scale. Using the samples collected from the MC plumes, we also aim to characterize the particles that were emitted from heavily polluted areas, where contributions of aerosol emissions to the regional and global environments are becoming increasingly important.

\section{Materials and methods}

\subsection{Mexico City atmospheric research projects}

The MILAGRO campaign was conducted in Mexico (Fig. 1) during March 2006 (Molina et al., 2008). The goal was to

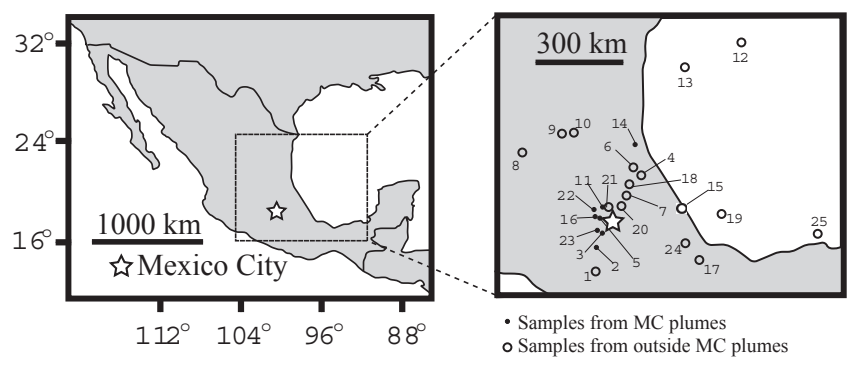

Fig. 1. Map showing sampling area. Sample numbers are shown in the right panel.

understand the evolution of trace gases and particles from anthropogenic emissions in and around MC as an example of a tropical megacity. Detailed meteorological conditions during the campaign are discussed in de Foy et al. (2008) and Fast et al. (2007). The prior MCMA-2003 (Mexico City Metropolitan Area field campaign 2003) also revealed important insights into the meteorology, primary pollutant emissions, ambient secondary pollutant precursor concentrations, photochemical oxidant production, and secondary aerosol particle formation in MC (Molina et al., 2007).

\subsection{Sampling}

Samples were collected using 3-stage impactor samplers (MPS-3, California Measurements, Inc.). Units were placed in both the NCAR/NSF C130 and the U.S. Forest Service Twin Otter (Yokelson et al., 2007) aircraft. Both contained isokinetic particle inlets with cutoff diameters of a few $\mu \mathrm{m}$ (Jonsson et al., 1995). The 50\% cut-off aerodynamic diameters of the samplers are 2.0, 0.3, and $0.05 \mu \mathrm{m}$. In this study, we used the smallest impactor stage $(0.05$ to $0.3 \mu \mathrm{m})$. Particles smaller than $50 \mathrm{~nm}$, which include individual or small clusters of soot spherules and freshly emitted sulfates and $\mathrm{OM}$, can have large number concentrations, especially during particle-formation events (Smith et al., 2008). However, such small particles generally coagulate rapidly after emission (Seinfeld and Pandis, 2006; Jacobson et al., 2005), and the mass and number fractions of soot particles smaller than $50 \mathrm{~nm}$ are small (Salcedo et al., 2006; Saathoff et al., 2003). Thus, our underestimate of the number of small particles has minor effects on conclusions based on total volume of particles in the air. Sampling times were mostly between 4 and $6 \mathrm{~min}$, although they ranged from 3 to $17 \mathrm{~min}$ (Table 1) depending on the particle concentrations.

Scanning electron microscope stubs, each having one TEM grid attached, were placed in each stage of the samplers. Lacy carbon grids were used for TEM sample collections. Such grids, which have "spider net" carbon substrates, are designed to be used for chemical analyses and high-resolution imaging (e.g., Figs. 2 and 3). The substrate causes minimal overlap with samples and yields clear images 

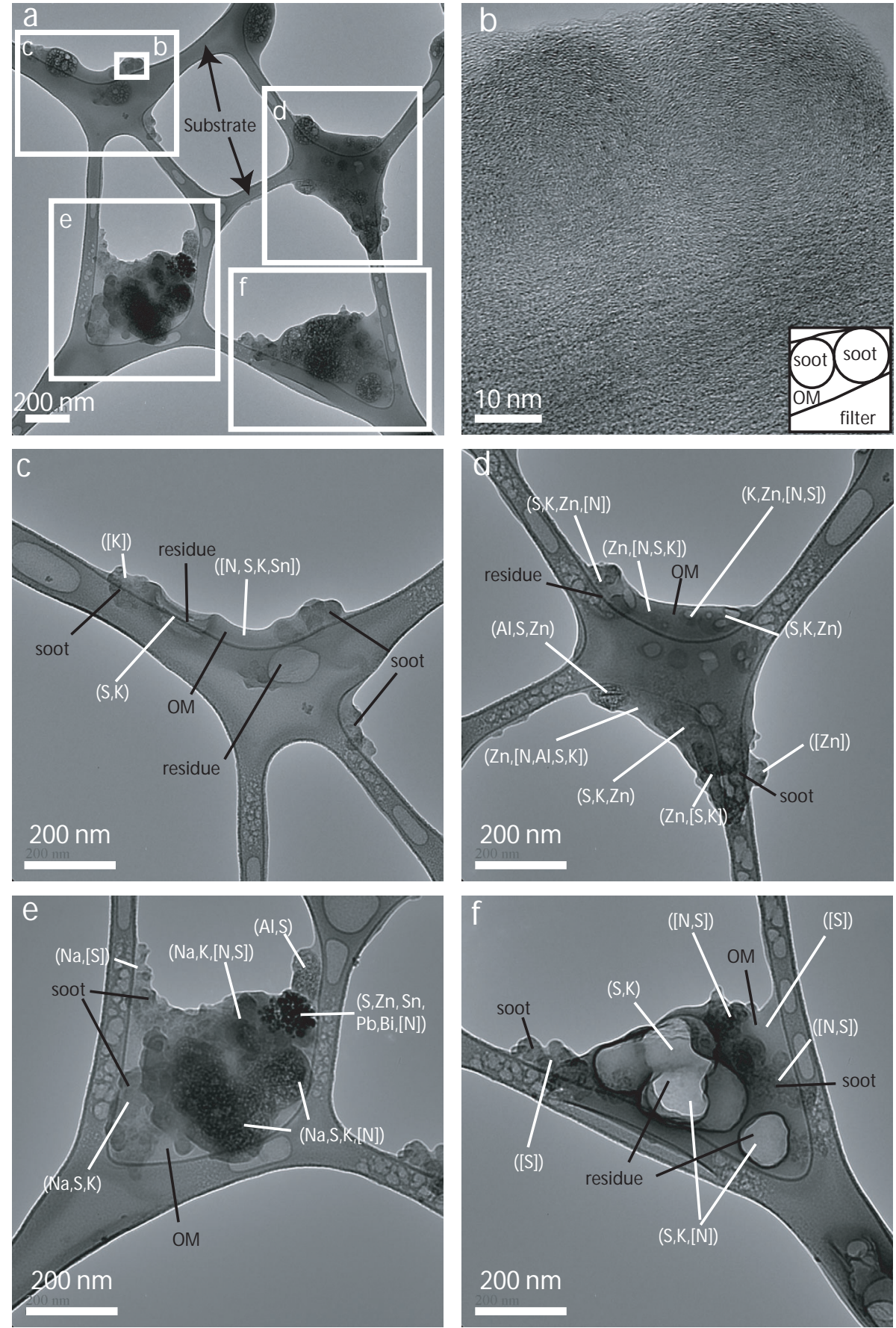

Fig. 2. Morphologies and compositions of internally mixed particles. Particles were deposited on lacy carbon filters. This sample was collected from MC (Sample \#3 in Table 1). EDS analyses typically indicate minor to trace amounts of the elements in the other phases. (a) Low-magnification image of particles c to f. (b) High-resolution image of soot particles, OM, and filter. The lower-right illustration shows a sketch of the image. Soot particles have curved graphitic layers. OM and the filter, both of which consist of amorphous carbon, have disordered structures. (c-f) Typical images of internally mixed particles; their compositions were obtained using EDS and are given in parentheses, with the results shown in white. Elements in square brackets are in concentrations $<1 \mathrm{wt} \%$. C, O, and $\mathrm{Si}$ occur in all particles and are not shown in the figure. Soot, OM, and residue, which are indicated using black lines, were identified from their morphological properties. 

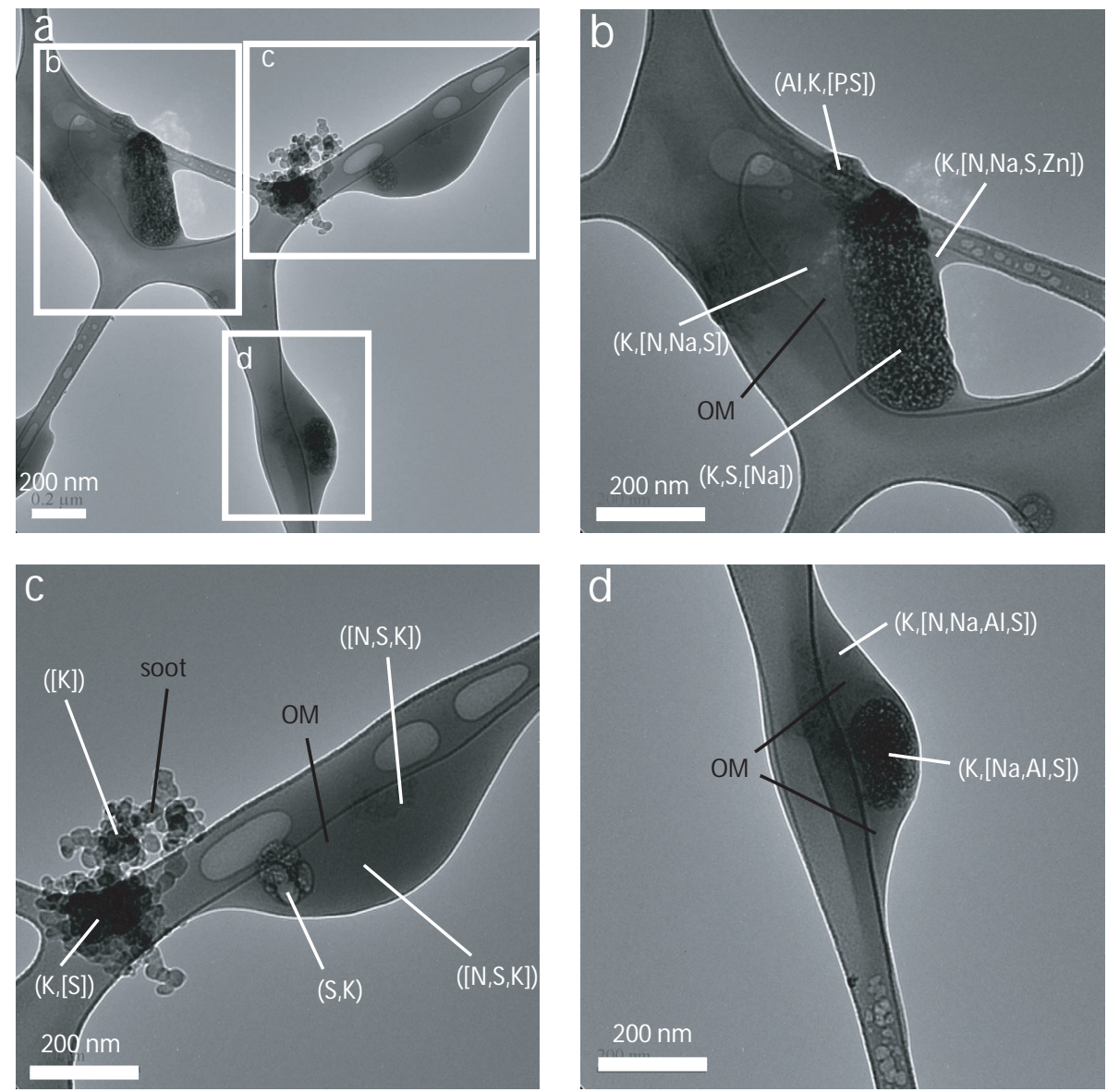

Fig. 3. Morphologies and compositions of externally mixed OM-S and soot particles. Experimental conditions are the same as those in Fig. 2.

where the particles extend over holes in the substrates (Pósfai et al., 2003).

We acquired 30 samples from the $\mathrm{C} 130$ during 10 research flights and 182 samples from the Twin Otter during 12 research flights. Some samples are primarily from the MC plumes and others from biomass burning. In this study we focus on the samples from the MC urban plumes and adjacent areas near MC (Fig. 1).

Samples were collected from a wide range of locations and weather conditions. We classified the samples as from either within the MC plume (MC sample, 8 samples) or outside of it (17 samples) using the HYSPLIT back-trajectory model of Draxler and Rolph (2003). Except for \#14, which was collected in a MC plume that was transported by a strong southwesterly wind toward the coastal Mexico-Texas border (Fast et al., 2007; Molina et al., 2008), all MC samples are from within $80 \mathrm{~km}$ of the city center (Table 1).

The ventilation of the MC basin is commonly rapid (de Foy et al., 2006, 2008; Molina et al., 2008). Residence time of the air in the basin is mostly less than $12 \mathrm{~h}$, with little carryover from day to day. Recirculation of air back into the basin is unusual. Thus, as most MC samples were collected around 2 p.m. local time (Table 1), most particles were within eight hours or less from emission. On the other hand, it is likely that samples from outside MC plumes are older than the MC samples, as most do not have definite sources within 1- to 2-day back-trajectories.

\subsection{TEM analysis}

We used a Tecnai F20 TEM for imaging and electron energyloss spectroscopy (EELS) analyses and a CM 200 TEM (both from the FEI Corp.) for energy-dispersive X-ray spectrometer (EDS) analyses. Both TEMs were operated at an accelerating voltage of $200 \mathrm{kV}$.

The EDS analyses were used to measure compositions of particles ranging from nanometers to micrometers in diameter. By using expanded electron beams that included entire particles $(\sim 1 \mu \mathrm{m})$, averaged compositions of individual particles were determined. We measured all particles in a certain area of a TEM image ( 2000 to $5000 \times$ magnification $)$ for the analyses. Each area had between 20 and 60 particles. We chose one or two areas from each of 12 samples 
Table 1. Samples analyzed in this study.

\begin{tabular}{|c|c|c|c|c|c|c|c|c|c|c|}
\hline Sample\# & Aircraft ${ }^{\mathrm{a}}$ & Latitude & Longitude & $\begin{array}{l}\text { Altitude } \\
(\mathrm{km})\end{array}$ & $\begin{array}{l}\text { Distance from } \\
\mathrm{MC}^{\mathrm{b}}(\mathrm{km})\end{array}$ & $\begin{array}{r}\text { Start time } \\
\text { (Local Time) }\end{array}$ & $\begin{array}{l}\text { Sampling time } \\
\text { (second) }\end{array}$ & $\begin{array}{l}\text { Sampling date } \\
(2006 /)\end{array}$ & Location $^{\mathrm{c}}$ & Analyses ${ }^{\mathrm{d}}$ \\
\hline 1 & $\mathrm{C} 130$ & 18.00 & 260.82 & 3.2 & 166 & $12: 27: 00$ & 266 & 03/08 & outside & S \\
\hline 2 & $\mathrm{C} 130$ & 18.81 & 260.79 & 3.0 & 79 & $14: 33: 52$ & 257 & 03/08 & MC & $\mathrm{S}$ \\
\hline 3 & $\mathrm{C} 130$ & 19.23 & 260.97 & 4.1 & 30 & $15: 17: 26$ & 277 & 03/08 & MC & $\mathrm{S} \& \mathrm{E}$ \\
\hline 4 & $\mathrm{C} 130$ & 21.00 & 262.27 & 2.4 & 216 & $10: 35: 25$ & 267 & $03 / 10$ & outside & $\mathrm{S}$ \\
\hline 5 & $\mathrm{C} 130$ & 19.71 & 260.86 & 3.7 & 28 & $14: 44: 45$ & 332 & $03 / 10$ & $\mathrm{MC}$ & $\mathrm{S} \& \mathrm{E}$ \\
\hline 6 & $\mathrm{C} 130$ & 21.30 & 261.87 & 3.0 & 220 & $13: 34: 12$ & 995 & $03 / 12$ & outside & $\mathrm{S}$ \\
\hline 7 & $\mathrm{C} 130$ & 20.41 & 261.84 & 3.5 & 136 & $17: 30: 01$ & 242 & $03 / 12$ & outside & S \\
\hline 8 & $\mathrm{C} 130$ & 21.50 & 258.34 & 2.8 & 367 & $11: 29: 16$ & 284 & $03 / 16$ & outside & $\mathrm{S} \& \mathrm{E}$ \\
\hline 9 & $\mathrm{C} 130$ & 22.20 & 259.75 & 4.1 & 327 & 10:50:02 & 346 & $03 / 18$ & outside & $\mathrm{S}$ \\
\hline 10 & $\mathrm{C} 130$ & 22.20 & 259.90 & 3.5 & 321 & $12: 32: 43$ & 250 & $03 / 18$ & outside & $\mathrm{S}$ \\
\hline 11 & $\mathrm{C} 130$ & 20.00 & 260.97 & 3.8 & 55 & $14: 54: 37$ & 255 & $03 / 18$ & $\mathrm{MC}$ & $\mathrm{S} \& \mathrm{E}$ \\
\hline 12 & $\mathrm{C} 130$ & 24.97 & 265.34 & 4.8 & 768 & $14: 44: 34$ & 248 & 03/19 & outside & S\&E \\
\hline 13 & $\mathrm{C} 130$ & 24.25 & 263.57 & 3.2 & 594 & $17: 13: 37$ & 246 & 03/19 & outside & S\&E \\
\hline 14 & $\mathrm{C} 130$ & 21.90 & 262.01 & 4.0 & 286 & $18: 29: 34$ & 247 & $03 / 19$ & $\mathrm{MC}$ & S\&E \\
\hline 15 & $\mathrm{C} 130$ & 20.08 & 263.53 & 4.2 & 286 & $11: 38: 48$ & 251 & $03 / 22$ & outside & $\mathrm{S}$ \\
\hline 16 & $\mathrm{C} 130$ & 19.73 & 260.73 & 4.1 & 40 & $14: 48: 55$ & 250 & $03 / 22$ & $\mathrm{MC}$ & $\mathrm{S}$ \\
\hline 17 & $\mathrm{C} 130$ & 18.53 & 264.01 & 4.8 & 348 & $16: 30: 04$ & 356 & $03 / 23$ & outside & S \\
\hline 18 & $\mathrm{C} 130$ & 20.64 & 261.84 & 4.1 & 155 & 5:33:08 & 309 & $03 / 28$ & outside & S \\
\hline 19 & $\mathrm{C} 130$ & 19.85 & 264.67 & 4.9 & 405 & $6: 30: 07$ & 310 & $03 / 28$ & outside & S \\
\hline 20 & $\mathrm{C} 130$ & 20.01 & 261.60 & 3.7 & 86 & $11: 32: 23$ & 348 & $03 / 29$ & outside & $\mathrm{S} \& \mathrm{E}$ \\
\hline 21 & $\mathrm{C} 130$ & 20.00 & 261.11 & 3.5 & 57 & $12: 55: 29$ & 256 & $03 / 29$ & outside & $\mathrm{S} \& \mathrm{E}$ \\
\hline 22 & $\mathrm{C} 130$ & 19.50 & 260.71 & 3.7 & 32 & $13: 38: 52$ & 249 & $03 / 29$ & $\mathrm{MC}$ & S \\
\hline 23 & TO & 19.32 & 260.82 & 4.1 & 28 & $15: 43: 33$ & 180 & $03 / 17$ & MC & $\mathrm{E}$ \\
\hline 24 & TO & 19.06 & 263.55 & 1.5 & 284 & $16: 58: 00$ & 300 & $03 / 28$ & outside & $\mathrm{E}$ \\
\hline 25 & TO & 19.17 & 267.82 & 3.7 & 751 & $16: 31: 00$ & 420 & $03 / 29$ & outside & $\mathrm{E}$ \\
\hline
\end{tabular}

${ }^{\mathrm{a}} \mathrm{TO}=$ Twin Otter. $^{\mathrm{b}} 19.5^{\circ} \mathrm{N}$ and $99^{\circ} \mathrm{W}$ are used for the center of MC.

${ }^{c}$ Outside indicates samples collected from outside of the MC plume. MC indicates samples collected from the MC plume.

${ }^{\mathrm{d}} \mathrm{S}$ indicates samples used for size measurements (Fig. 5) and number fraction analysis (Fig. 6), and E indicates samples used for EDS analysis. Samples marked S\&E were used for both types of analyses.

and analyzed 379 particles in total (Table 1). Thirty-second collection times were used.

\subsection{Soot particles, organic matter (OM), and sulfates}

Soot particles from MC typically consist of aggregated carbonaceous spherules ranging in diameter from 20 to $100 \mathrm{~nm}$, with median value about $44 \mathrm{~nm}$. They contain poorly ordered, curved graphitic layers separated by $\sim 0.36 \mathrm{~nm}$ (Fig. 2b) and display a sharp $\pi^{*}$ peak in EELS analyses. Soot particles can be recognized by their graphitic structure in TEM images even where they are internally mixed with OM, which is typically amorphous. The structural difference causes contrast in TEM images. However, if the grains are too thick $(\sim 1 \mu \mathrm{m})$, it can be difficult to identify the soot particles. Therefore, although such thick grains are not common in our samples, our values for the number and volume of internally mixed soot particles could be underestimates. Soot particles in MC are mainly from vehicles, but some come from biomass burning (Moffet et al., 2008; Jiang et al., 2005), residential combustion of wood (biofuel burning), and aircraft (Bond et al., 2004; Mexico National Emissions Inventory 1999, 2006).
OM commonly coats the surfaces of soot, sulfates, and mineral dust in our samples (Figs. 2, 3, and 4). In MC, about half the organic carbon comes from motor vehicles, and from 5 to $26 \%$ of organic carbon is from biomass burning (Stone et al., 2008). Except for tar balls, which are spherical (Pósfai et al., 2004; Hand et al., 2005), OM lacks a distinctive morphology. OM particles are less sensitive to the electron beam than sulfates, although they shrink slightly after strong radiation.

The sulfates readily decompose when exposed to an electron beam. Many are coated with OM and, when decomposing, they leave a carbonaceous residue (Fig. 2c, d, f) (Pósfai et al., 2003). We used Ca-coated TEM grids to detect $\mathrm{H}_{2} \mathrm{SO}_{4}$ and $\left(\mathrm{NH}_{4}\right)_{2} \mathrm{SO}_{4}$ using the same method as Kojima et al. (2006), Yamato and Ono (1989), and Yamato and Tanaka (1994). Most droplets did not react with the Ca coatings, which we interpret as indicating our sulfates had been neutralized by ammonium. Such neutralization is consistent with the results of DeCarlo et al. (2007) and Moya et al. (2003). The $\mathrm{S}$ that forms the sulfate comes from regional sources such as petrochemical and power plants, volcanic emissions (Grutter et al., 2008; Johnson et al., 2006; de Foy et al., 
2007; DeCarlo et al., 2008), and gasoline and diesel fuel, both of which contain $>300 \mathrm{ppm}$ of S in Mexico (Molina and Molina, 2002).

\subsection{Particle classification}

For purposes of this study, we classified particles into categories based on their morphological features described above: 1) internally mixed soot particles (soot with coatings of OM, sulfates, or both; hereafter, we will refer to mixtures of OM and sulfate as OM-S);2) soot particles without coatings (externally mixed soot); 3) OM-S without soot; 4) tar balls; and 5) others. Category 1 includes soot particles that were attached to or partly coated by OM-S (soot size $>$ OMS size), which constitute $\sim 20 \%$ of this category, and particles that have both soot and mineral or metal particles with OM-S coatings. If no coatings were recognized in the TEM images, the soot particles were included in category 2. Tar balls (category 4) are amorphous, spherical, carbonaceous particles. They are easy to recognize because they are not normally mixed with other materials and are relatively transparent in TEM images (Pósfai et al., 2004). All other particles were classified as category 5 and are mostly mineral dust and metal particles, all of which are crystalline and resist decomposition in the electron beam.

\subsection{Particle selection}

For particle measurements, we selected a single grid square $(125 \times 125 \mu \mathrm{m})$ from a TEM grid of each sample, using the same method as Kojima et al. (2004). Between 100 and 300 TEM images were recorded for each sample. All particles with diameters greater than $50 \mathrm{~nm}$ in those TEM images, typically between 300 and 600 particles per sample, were sized and categorized. A total of more than 7700 particles from 22 samples were used for size measurements and particle categorization (Table 1). The procedure produces uncertainties of less than $10 \%$ relative in the pie chart (Fig. 6).

\subsection{Particle size measurements}

Averaged particle radii were determined by fitting ellipses to the particle outlines and taking the geometric mean of the semi-minor and semi-major axes (Pósfai et al., 2003; Mogo et al., 2005). If more than two soot-particle aggregates occur in an internal mixture, only the larger one was measured. The rationale was that these larger soot particles have the greatest effect on the particle optical properties.

Many particles containing OM-S were apparently liquid or at least relatively viscous when collected. In these instances, they spread when on the grid (Figs. 2 and 3). Assuming OM$S$ particles without soot (category 3) were spherical in the atmosphere, our measurements of those collected on TEM grids possibly overestimate their sizes by about $10 \%$. We used lacy-carbon support films to minimize the effect. In some cases, they may have decreased in size because of loss

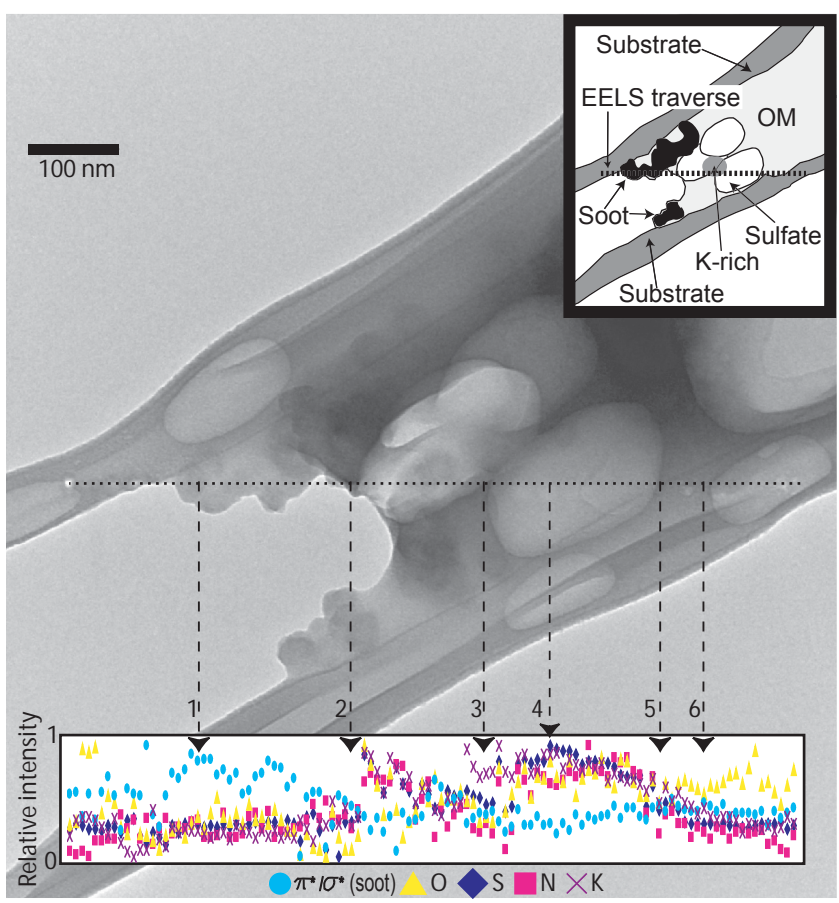

Fig. 4. Plot of composition vs. position in the internally mixed particle from the MC pollution plume (Sample \#3). The sketch in the upper right shows the various species. Points 1 - soot, 2 - OM, 3 K-rich particle, 4 - sulfate decomposition residue, 5 - OM, 6 - lacycarbon filter. A total of 114 points were analyzed by using EELS at $10 \mathrm{~nm}$ intervals. The $\pi^{*}$ and $\sigma^{*}$ intensities were obtained by using the same method as Katrinak et al. (1992). We used intensities at $184.5,294.5 / \sigma^{*}$, and $402.5 \mathrm{eV}$ in the EELS spectra for determining the relative abundances of $\mathrm{S}, \mathrm{K}$, and $\mathrm{N}$, respectively. For O, total counts ranging from 531.5 to $536.5 \mathrm{eV}$ were used. Exponential background extractions were applied.

of volatile fractions. Vacuum condition causes $\sim 20 \%$ shrinkage for ammonium sulfate particles (Pósfai et al., 1998). We used the same procedure for all samples, and therefore the comparison among our samples is internally consistent.

\section{Results}

\subsection{Nature of aerosol particles}

We found that many MC particles are internally mixed. This observation is consistent with the results from single-particle mass spectrometer measurements (Moffet et al., 2008) and scanning and transmission electron microscopy (Doran et al., 2008; Johnson et al., 2005), all of which were used to analyze MC samples.

Images of many MC particles show the intimate mixtures of constituent phases. Typical images and compositions of both internally and externally mixed particles are shown in Figs. 2 and 3, respectively. 

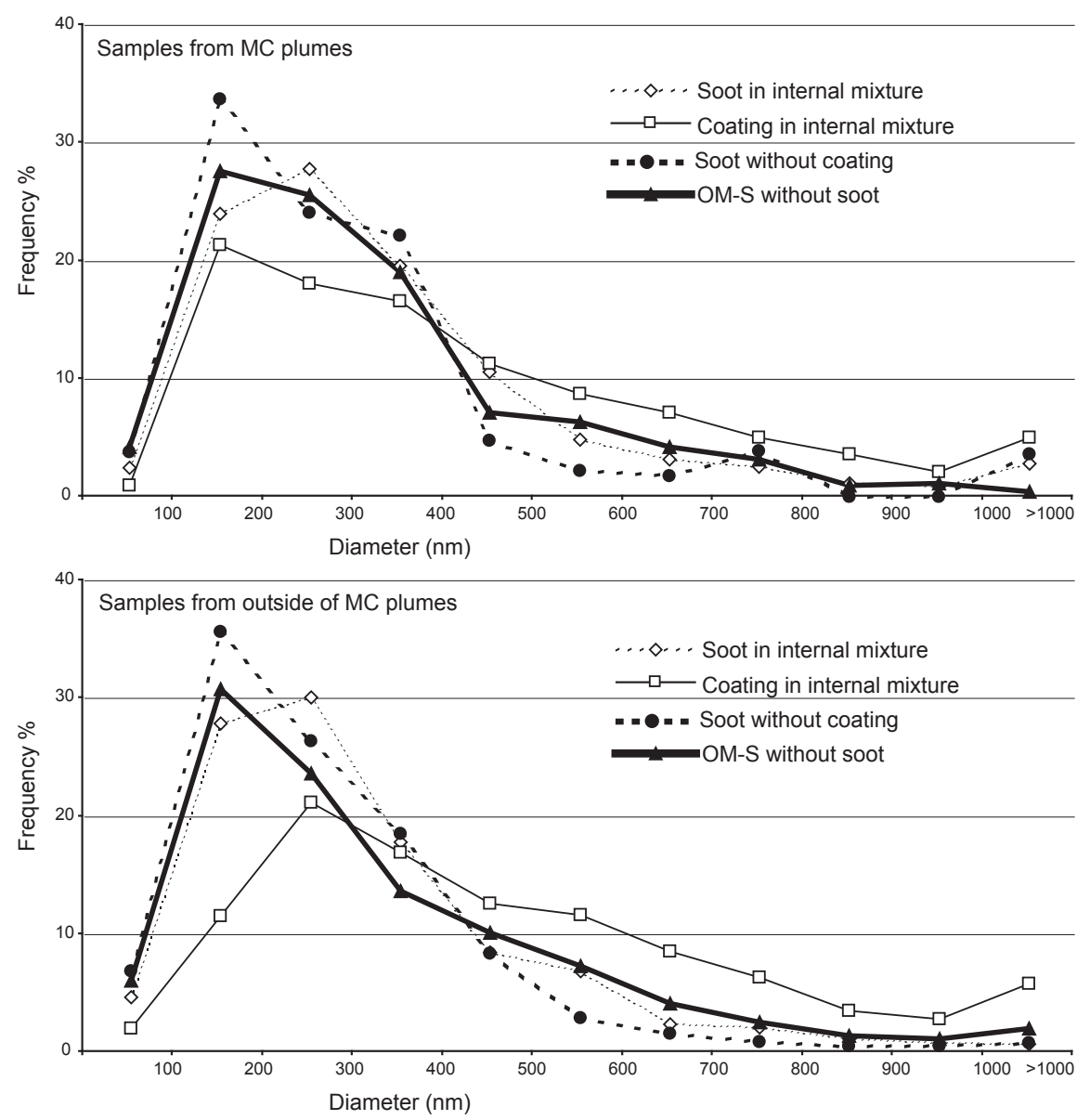

Fig. 5. Distributions of particle diameters. Total numbers of internally mixed particles, soot without coatings, and OM-S without soot are 1312,176 , and 789, respectively, and those of the samples from outside MC are 1492, 378, and 2989, respectively.

EDS measurements show that S occurs in more than $90 \%$ of all analyzed particles, and more than $70 \%$ of these also contain K. Since most such S-bearing particles were sensitive to the electron beam, we interpreted them as sulfates (possibly mixtures of $\mathrm{K}_{2} \mathrm{SO}_{4},\left(\mathrm{NH}_{4}\right)_{2} \mathrm{SO}_{4}$, and $\mathrm{NH}_{4} \mathrm{HSO}_{4}$ ) (Pósfai et al., 1995; Kojima et al., 2004). Si occurs in 75\% of the particles, although discrete mineral grains were not evident. Small peaks in the EDS spectra showed one or more of $\mathrm{V}, \mathrm{Cr}, \mathrm{Mn}, \mathrm{Ni}, \mathrm{Zn}, \mathrm{Sn}, \mathrm{Pb}$, and $\mathrm{Bi}$ in $50 \%$ of the particles. Other studies also reported metals in MC aerosol particles (e.g., Moffet et al., 2008; Chow et al., 2002; Johnson et al., 2006; Querol et al., 2008).

In order to explore details of the sorts of particles typical of the MC plume, we show a set of EELS analyses across a traverse of one such composite particle (Fig. 4). A plot of $\mathrm{S}, \mathrm{O}, \mathrm{N}$, and $\mathrm{K}$ composition vs. position shows a sulfate decomposition residue (e.g., Point 4 in Fig. 4). The high $\pi * / \sigma *$ ratios at, e.g., point 1 , confirm the identity of soot. The low $\pi * / \sigma *$ ratios at points 2 and 5 and the lack of a well-defined shape are consistent with the identity of OM.

\subsection{Sizes and aspect ratios of aerosol particles}

The size distributions of MC samples are similar to those collected outside of MC (Fig. 5). However, the peak of the distribution for internally mixed OM-S coatings from the MC samples occurs for smaller particles than for those collected outside of MC. A possible explanation is that the MC samples include more young particles, which had less time for growth through coagulation. The median diameter of particles containing soot and OM-S coatings (thin solid line in Fig. 5) is about $290 \mathrm{~nm}$ and that of OM-S particles without soot (thick solid line in Fig. 5) is about $170 \mathrm{~nm}$. i.e., coated particles tend to be larger.

The aspect ratio (long axis/short axis) is an indicator of compactness. Averaged aspect ratios (and standard deviations) are $2.2(0.9), 2.1(0.9)$, and $1.9(0.8)$ for uncoated soot and that with coatings from $\mathrm{MC}$ and outside of $\mathrm{MC}$, respectively. Those in our samples are not highly compacted but retain their chain-like structure. 


\subsection{Volumes and number fractions of aerosol particles}

The volumes of particles are important for evaluating their optical properties and aging. Most particles have irregular shapes on TEM grids, but many were presumably liquid within the atmosphere. For simplification, we approximated their shapes as roughly elliptical when on the TEM grid. We used their measured semi-major and semi-minor axes to calculate their volumes. The volumes, $V$, of the soot particles within the internally mixed particles were determined using the relation $V=4 / 3 \times \pi \times a^{3} \times N$, where $a$ is the radius and $N$ is the number of soot spherules in an aggregate particle. $N$ was estimated from the statistical scaling law of fractal aggregates, $N=k_{a} \times\left(R_{g} / a\right)^{D f}$, where $k_{a}$ is the structural coefficient, $R_{g}$ is the radius of gyration, and $D_{f}$ is the fractal dimension (Adachi et al., 2007). We used the measured semimajor axes of soot particles for determination of $R_{g}\left(R_{g}=\right.$ semi-major axis/1.5) (Brasil et al., 2001; Köylü et al., 1995; Gwaze et al., 2006). For simplification, we divided the soot particles into their end values of either open or compact. For soot particles that have aspect ratios $>2.0$ (open clusters), we used $D_{f}=2.4$ and $k_{a}=0.7$ (Adachi et al., 2007). For the compacted soot particles (aspect ratios $\leq 2.0$ ), we used $D_{f}=2.6$ and $k_{a}=2.1$ (Adachi et al., 2007; Liu and Mishchenko, 2005).

Approximately $80 \%$ and $50 \%$ by volume of the OM-S particles collected from MC and outside of MC, respectively, contained soot particles. The median value of soot volume fractions for internally mixed particles is $15 \%$ when the median value of $a=22 \mathrm{~nm}$ is used and goes from 7 to $24 \%$ for our range of $a$ values (from 10 to $50 \mathrm{~nm}$ ) and for $D_{f} \pm 0.2$ from the $D_{f}$ values shown above.

The number fractions of the major particle types also indicate that internally mixed particles dominated the MC samples (Fig. 6). Soot occurs in 62 and 35\% of all particles in the samples from MC and outside MC, respectively, and more than $80 \%$ of the particles were coated by OM-S in both sample sets.

\section{Discussion}

\subsection{OM-S coatings on soot particles}

The proportion of particles containing internally mixed soot is higher than that reported by Okada et al. (2005) for Australia, Hara et al. (2003) for the Arctic, and Hasegawa and Ohta (2002) for Japan and Alaska, even though most of our MC samples were less aged. Since our MC samples were collected close to their sources, generally within less than eight hours after emission and yet were coated when collected, we conclude that the rate of coating was rapid, consistent with the results of Doran et al. (2007), Johnson et al. (2005), and Baumgardner et al. (2007). The rate is much faster than that used in climate models. For example, Cooke et al. (1999) suggested that an exponential lifetime of hy-
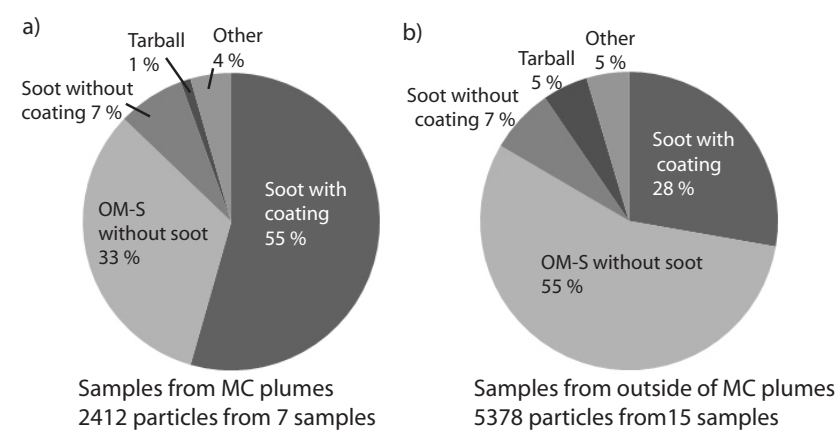

Fig. 6. Number fraction of particles.

drophobic soot is 1.15 days. Coated soot particles are removed by wet deposition and have shorter lifetimes, which reduce their radiative forcing (van Poppel et al., 2005).

The coated soot particles retained their chain-like structures as judged from TEM images and measured aspect ratios. A possible explanation is that rapidly deposited coatings covered the entire soot particle and fixed its structure before it became completely compacted.

Light absorption of soot is enhanced when it is coated by OM-S, which focuses sunlight on the soot and also enlarges the available absorption cross section (Fuller et al., 1999; Chýlek et al., 1995; Bond et al., 2006; Barnard et al., 2007). In our samples, the median coating fraction is $85 \%$ by volume in internally mixed particles. Mie calculations show that a spherical soot core surrounded by a concentric shell has its absorption enhanced by roughly 1.5 relative to one without a coating (Bond et al., 2006). However, such a configuration probably overestimates the light absorption of our soot particles that are not completely compacted because soot spherules located away from the center of the particle have reduced absorption (Fuller et al., 1999; Bond et al., 2006).

Secondary organic aerosol particles form through condensation of precursor gases on pre-existing particles such as soot, ammonium sulfate, and primary organic aerosol as well as through homogeneous nucleation (Seinfeld and Pankow, 2003). In our samples, we observed such secondary organic aerosol particles as the coatings on soot. Soot occurs in $62 \%$ of our OM-S particles, and $80 \%$ by volume of all OM-S particles contain soot. Additionally, OM-S particles that contain soot are larger than those that do not (Fig. 5). These results imply that soot particles are important nuclei for the development of secondary organic aerosol particles in MC.

\subsection{Contributions from biomass and biofuel burning}

Biomass and biofuel burning are major sources of aerosol particles in MC (Moffet et al., 2008; Stone et al., 2008; Yokelson et al., 2007). K is a key element for identifying such particles (Andreae, 1983; Li et al., 2003; Pósfai et al., 2003; Hudson et al., 2004; Murphy et al., 2006). In our samples, $\mathrm{K}$ occurs in more than $60 \%$ of the particles, most 
of which are sulfates. Sulfate condensation on the biomassburning particles probably occurred during transport, as was also observed in biomass-burning particles in southern Africa (Pósfai et al., 2003; Gaudichet et al., 1995 Andreae et al., 1998; Gao et al., 2003; Kreidenweis et al., 2001; Liu et al., 2000).

$\mathrm{K}$ concentrations are variable among particles (Figs. 2, 3, 4). Some were presumably produced by biomass burning outside of MC. Such burning occurred during the campaign in the central and southern parts of Mexico such as Yucatan and around MC (Yokelson et al., 2007; Fast et al., 2007). Locally, residential wood combustion (biofuel burning) is another source of K-bearing particles (Moffet et al., 2008; Mexico National Emissions Inventory 1999, 2006).

Tar balls are also an indicator of biomass and biofuel burning (Pósfai et al., 2004). Their number fractions were smaller than those in other areas that had large contributions of biomass and biofuel burning such as southern Africa, Hungary (Pósfai et al., 2004), and Yosemite National Park (Hand et al., 2005). The relatively low biomass- and biofuelburning contributions to bulk samples are consistent with the study by Stone et al. (2008), although our findings suggest they make important contributions since they occur in many individual particles.

\subsection{Sulfate implications}

Sulfate particles are attached to OM, soot, or their mixtures, or are embedded in OM (Fig. 2). They are commonly smaller than $200 \mathrm{~nm}$ across. Although in areas such as the northern Atlantic Ocean (Pósfai et al., 1999) and southern Finland (Niemi et al., 2006), sulfates encapsulate entire soot particles, the dominant material in the MC samples is $\mathrm{OM}$, and the sulfate as well as soot is either embedded within the OM or attached to its edges. The difference arises because the MC plume included large quantities of OM (Salcedo et al., 2006; Jiang et al., 2005; Zavala et al., 2006; Stone et al., 2008; Querol et al., 2008; Takahama et al., 2007; DeCarlo et al., 2008; Molina et al., 2007; Kleinman et al., 2008), which produced coatings on the soot prior to the development of the sulfate particles.

The attached sulfates hardly enhance the light absorption of soot (Mishchenko et al., 2004). On the other hand, sulfates can change the OM and soot particles from hydrophobic to hydrophilic and eventually make them efficient cloud condensation nuclei (CCN) (Lohmann et al., 2004; King et al., 2007). Meanwhile, those embedded in hydrophobic OM do not work well as CCN (Abbatt et al., 2005, King et al., 2007). Since we found some sulfates embedded in OM, their $\mathrm{CCN}$ properties will be overestimated if all are assumed to be on the surface. Although instruments such as single-particle mass spectrometers can rapidly determine particle compositions, the morphologies of individual particles, which are only obtained by using electron microscopy, are important for interpreting their contributions to climate, e.g., as $\mathrm{CCN}$.

\section{Conclusions}

Over 50\% of the aerosol particles that we sampled from the MC plume consist of internally mixed soot, OM, and sulfates. MC sulfate commonly contains $\mathrm{K}$, suggesting contributions from biomass and biofuel burning. These findings indicate that individual particles typically contain materials from multiple sources. $\mathrm{OM}$ is a dominant material in the MC plume, and soot particles are common. As a result, OM rapidly coats most soot particles. Additionally, attached sulfate on $\mathrm{OM}$ and soot particles possibly changes them from hydrophobic to hydrophilic.

In a city where pollution is heavy and formation of secondary organics is rapid, as is the case in MC, assuming that soot particles are internally mixed is relatively reliable for modeling. Our results also imply that, depending on their nature, the coatings can have either negative or positive effects on the radiative forcing. They reduce soot lifetimes in the atmosphere through the changes in particle hygroscopicity and increased mass, which together result in both washout and dry deposition and, on the other hand, they amplify light absorption. Their complicated morphologies also suggest that coated soot particles will not enhance light absorption as efficiently as those assumed in many climate models. Since soot is the dominant primary particle in many urban areas, its properties, especially when coated, are important for accurate evaluation of its effects on local and regional climate. Moreover, soot occurs in more than $60 \%$ of all particles in the MC plumes, suggesting its central role in the formation of secondary aerosol particles.

Acknowledgements. The authors thank T. Karl, F. Flocke, and S. Madronich for their help with collection of the C130 samples and R. Yokelson, T. Christian, S. Urbanski, C. Wold, D. Toohey, M. Fisher, E. Thompson, G. Moore, J. Stright, A. Knobloch, and K. Bailey for their help with collection of Twin Otter samples. C. Wilson and J. Cagle helped greatly with the aircraft inlets. We are grateful to E. Freney, L. Garvie, and S. H. Chung for their discussions of this manuscript. We gratefully acknowledge the use of TEMs within the LeRoy Eyring Center for Solid State Science at Arizona State University. This study was supported by NSF grant ATM-0531926.

Edited by: S. Madronich

\section{References}

Abbatt, J. P. D., Broekhuizen, K., and Kumal, P. P.: Cloud condensation nucleus activity of internally mixed ammonium sulfate/organic acid aerosol particles, Atmos. Environ., 39, 47674778, 2005.

Abel, S. J., Haywood, J. M., Highwood, E. J., Li, J., and Buseck, P. R.: Evolution of biomass burning aerosol properties from an agricultural fire in southern Africa, Geophys. Res. Lett., 30, 1783, doi:10.1029/2003GL017342, 2003.

Adachi, K., Chung, S. H., Friedrich, H., and Buseck, P. R.: Fractal parameters of individual soot particles determined using elec- 
tron tomography: Implications for optical properties, J. Geophys. Res.-Atmos., 112, D14202, doi:10.1029/2006JD8296, 2007.

Andreae, M. O.: Soot carbon and excess fine potassium: long-range transport of combustion-derived aerosols, Science, 220, 11481151, 1983.

Andreae, M. O., Andreae, T. W., Annegarn, H., Beer, J., Cachier, H., Le Canut, P., Elbert, W., Maenhaut, W., Salma, I., Wienhold, F. G., and Zenker, T.: Airborne studies of aerosol emissions from savanna fires in southern Africa: 2. Aerosol chemical composition, J. Geophys. Res.-Atmos., 103, 32 119-32 128, 1998.

Barnard, J. C., Kassianov, E. I., Ackerman, T. P., Johnson, K., Zuberi, B., Molina, L. T., and Molina, M. J.: Estimation of a "radiatively correct" black carbon specific absorption during the Mexico City Metropolitan Area (MCMA) 2003 field campaign, Atmos. Chem. Phys., 7, 1645-1655, 2007,

http://www.atmos-chem-phys.net/7/1645/2007/.

Baumgardner, D., Kok, G. L., and Raga, G. B.: On the diurnal variability of particle properties related to light absorbing carbon in Mexico City, Atmos. Chem. Phys., 7, 2517-2526, 2007, http://www.atmos-chem-phys.net/7/2517/2007/.

Bohren, C. F. and Huffman, D. R.: Absorption and scattering of light by small particles, Wiley-VCH, Berlin, 1983.

Bond, T. C. and Bergstrom, R. W.: Light absorption by carbonaceous particles: An investigative review, Aerosol Sci. Technol., 40, 27-67, 2006.

Bond, T. C., Habib, G., and Bergstrom, R. W.: Limitations in the enhancement of visible light absorption due to mixing state, J. Geophys. Res.-Atmos., 111, D20211, doi:10.1029/2006JD007315, 2006.

Brasil, A. M., Farias, T. L., Carvalho, M. G., and Koylu, U. O.: Numerical characterization of the morphology of aggregated particles, J. Aerosol Sci., 32, 489-508, 2001.

Buseck, P. R. and Pósfai, M.: Airborne minerals and related aerosol particles: Effects on climate and the environment, P. Natl. Acad. Sci. USA., 96, 3372-3379, 1999.

Buseck, P. R. and Schwartz, S. E.: Tropospheric aerosols, in: Treatise on Geochemistry, Vol. 4, edited by: Turekian, K. K. and Holland, H. D., Elsevier Science Ltd., San Diego, 91-142, 2003.

Chen, Y. Z., Shah, N., Huggins, F. E., and Huffman, G. P.: Microanalysis of ambient particles from Lexington, KY, by electron microscopy, Atmos. Environ., 40, 651-663, 2006.

Chow, J. C., Watson, J. G., Edgerton, S. A., and Vega, E.: Chemical composition of PM2.5 and PM10 in Mexico City during winter 1997, Sci. Total Environ., 287, 177-201, 2002.

Chung, S. H. and Seinfeld, J. H.: Global distribution and climate forcing of carbonaceous aerosols, J. Geophys. Res.-Atmos., 107(D19), 4407, doi:10.1029/2001JD001397, 2002.

Chung, S. H. and Seinfeld, J. H.: Climate response of direct radiative forcing of anthropogenic black carbon, J. Geophys. Res.Atmos., 110, D11102, doi:10.1029/2004JD005441, 2005.

Chýlek, P., Videen, G., Ngo, D., Pinnick, R. G., and Klett, J. D.: Effect of black carbon on the optical properties and climate forcing of sulfate aerosols, J. Geophys. Res.-Atmos., 100, 1632516332, 1995.

Cooke, W. F., Liousse, C., Cachier, H., and Feichter, J.: Construction of a 1 degrees $\mathrm{x} 1$ degrees fossil fuel emission data set for carbonaceous aerosol and implementation and radiative impact in the ECHAM4 model, J. Geophys. Res.-Atmos., 104, 22 137$22162,1999$. de Foy, B., Fast, J. D., Paech, S. J., Phillips, D., Walters, J. T., Coulter, R. L., Martin, T. J., Pekour, M. S., Shaw, W. J., Kastendeuch, P. P., Marley, N. A., Retama, A., and Molina, L. T.: Basinscale wind transport during the MILAGRO field campaign and comparison to climatology using cluster analysis, Atmos. Chem. Phys., 8, 1209-1224, 2008,

http://www.atmos-chem-phys.net/8/1209/2008/.

de Foy, B., Lei, W., Zavala, M., Volkamer, R., Samuelsson, J., Mellqvist, J., Galle, B., Martnez, A.-P., Grutter, M., Retama, A., and Molina, L. T.: Modelling constraints on the emission inventory and on vertical dispersion for $\mathrm{CO}$ and $\mathrm{SO}_{2}$ in the Mexico City Metropolitan Area using Solar FTIR and zenith sky UV spectroscopy, Atmos. Chem. Phys., 7, 781-801, 2007,

http://www.atmos-chem-phys.net/7/781/2007/.

de Foy, B., Varela, J. R., Molina, L. T., and Molina, M. J.: Rapid ventilation of the Mexico City basin and regional fate of the urban plume, Atmos. Chem. Phys., 6, 2321-2335, 2006, http://www.atmos-chem-phys.net/6/2321/2006/.

DeCarlo, P. F., Dunlea, E. J., Kimmel, J. R., Aiken, A. C., Sueper, D., Crounse, J., Wennberg, P. O., Emmons, L., Shinozuka, Y., Clarke, A., Zhou, J., Tomlinson, J., Collins, D. R., Knapp, D., Weinheimer, A. J., Montzka, D. D., Campos, T., and Jimenez, J. L.: Fast airborne aerosol size and chemistry measurements above Mexico City and Central Mexico during the MILAGRO campaign, Atmos. Chem. Phys., 8, 4027-4048, 2008, http://www.atmos-chem-phys.net/8/4027/2008/.

Dockery, D. W., Pope, C. A., Xu, X. P., Spengler, J. D., Ware, J. H., Fay, M. E., Ferris, B. G., and Speizer, F. E.: An association between air pollution and mortality in 6 United States cities, New Engl. J. Med., 329, 1753-1759, 1993.

Doran, J. C., Barnard, J. C., Arnott, W. P., Cary, R., Coulter, R., Fast, J. D., Kassianov, E. I., Kleinman, L., Laulainen, N. S., Martin, T., Paredes-Miranda, G., Pekour, M. S., Shaw, W. J., Smith, D. F., Springston, S. R., and Yu, X.-Y.: The T1-T2 study: evolution of aerosol properties downwind of Mexico City, Atmos. Chem. Phys., 7, 1585-1598, 2007, http://www.atmos-chem-phys.net/7/1585/2007/.

Doran, J. C., Fast, J. D., Barnard, J. C., Laskin, A., Desyaterik, Y., and Gilles, M. K.: Applications of lagrangian dispersion modeling to the analysis of changes in the specific absorption of elemental carbon, Atmos. Chem. Phys., 8, 1377-1389, 2008, http://www.atmos-chem-phys.net/8/1377/2008/.

Draxler, R. R. and Rolph, G. D.: HYSPLIT (HYbrid Single-Particle Lagrangian Integrated Trajectory) Model access via NOAA ARL READY Website (http://www.arl.noaa.gov/ready/hysplit4.html), NOAA Air Resources Laboratory, Silver Spring, MD, 2003.

Fast, J. D., de Foy, B., Acevedo Rosas, F., Caetano, E., Carmichael, G., Emmons, L., McKenna, D., Mena, M., Skamarock, W., Tie, X., Coulter, R. L., Barnard, J. C., Wiedinmyer, C., and Madronich, S.: A meteorological overview of the MILAGRO field campaigns, Atmos. Chem. Phys., 7, 2233-2257, 2007, http://www.atmos-chem-phys.net/7/2233/2007/.

Fuller, K. A., Malm, W. C., and Kreidenweis, S. M.: Effects of mixing on extinction by carbonaceous particles, J. Geophys. Res.Atmos., 104, 15 941-15 954, 1999.

Gao, S., Hegg, D. A., Hobbs, P. V., Kirchstetter, T. W., Magi, B. I., and Sadilek, M.: Water-soluble organic components in aerosols associated with savanna fires in southern Africa: Identification, evolution, and distribution, J. Geophys. Res.-Atmos., 108(D13), 
8491, doi:10.1029/2002JD002324, 2003.

Gaudichet, A., Echalar, F., Chatenet, B., Quisefit, J. P., Malingre, G., Cachier, H., Buatmenard, P., Artaxo, P., and Maenhaut, W.: Trace elements in tropical African savanna biomass burning aerosols, J. Atmos. Chem., 22, 19-39, 1995.

Grutter, M., Basaldud, R., Rivera, C., Harig, R., Junkerman, W., Caetano, E., and Delgado-Granados, $\mathrm{H} .: \mathrm{SO}_{2}$ emissions from Popocatépetl volcano: emission rates and plume imaging using optical remote sensing techniques, Atmos. Chem. Phys. Discuss., 8, 8119-8141, 2008,

http://www.atmos-chem-phys-discuss.net/8/8119/2008/.

Gwaze, P., Schmid, O., Annegarn, H. J., Andreae, M. O., Huth, J., and Helas, G.: Comparison of three methods of fractal analysis applied to soot aggregates from wood combustion, J. Aerosol Sci., 37, 820-838, 2006.

Hand, J. L., Malm, W. C., Laskin, A., Day, D., Lee, T., Wang, C., Carrico, C., Carrillo, J., Cowin, J. P., Collett, J., and Iedema, M. J.: Optical, physical, and chemical properties of tar balls observed during the Yosemite Aerosol Characterization Study, J. Geophys. Res.-Atmos., 110, D21210, doi:10.1029/2004JD005728, 2005.

Hara, K., Yamagata, S., Yamanouchi, T., Sato, K., Herber, A., Iwasaka, Y., Nagatani, M., and Nakata, H.: Mixing states of individual aerosol particles in spring Arctic troposphere during ASTAR 2000 campaign, J. Geophys. Res.-Atmos., 108(D7), 4209, doi:10.1029/2002JD002513, 2003.

Hasegawa, S. and Ohta, S.: Some measurements of the mixing state of soot-containing particles at urban and non-urban sites, Atmos. Environ., 36, 3899-3908, 2002.

Haywood, J. M., Roberts, D. L., Slingo, A., Edwards, J. M., and Shine, K. P.: General circulation model calculations of the direct radiative forcing by anthropogenic sulfate and fossil-fuel soot aerosol, J. Climate, 10, 1562-1577, 1997.

Hudson, P. K., Murphy, D. M., Cziczo, D. J., Thomson, D. S., De Gouw, J. A., Warneke, C., Holloway, J., Jost, J. R., and Hübler, G.: Biomass-burning particle measurements: Characteristic composition and chemical processing, J. Geophys. Res.Atmos., 109, D23S27, doi:10.1029/2003JD004398, 2004.

IPCC: Climate Change 2007: The Physical Science Basis, Contribution of Working Group I to the Fourth Assessment Report of the Intergovernmental Panel on Climate Change, edited by: Solomon, S., Qin, D., Manning, M., Chen, Z., Marquis, M., Averyt, K. B., Tignor, M., and Miller, H. L., Cambridge University Press, Cambridge, United Kingdom and New York, NY, USA, 996 pp., 2007.

Jacobson, M. Z.: Strong radiative heating due to the mixing state of black carbon in atmospheric aerosols, Nature, 409, 695-697, 2001.

Jacobson, M. Z., Kittelson, D. B., and Watts, W. F.: Enhanced coagulation due to evaporation and its effect on nanoparticle evolution, Environ. Sci. Technol., 39, 9486-9492, 2005.

Jiang, M., Marr, L. C., Dunlea, E. J., Herndon, S. C., Jayne, J. T., Kolb, C. E., Knighton, W. B., Rogers, T. M., Zavala, M., Molina, L. T., and Molina, M. J.: Vehicle fleet emissions of black carbon, polycyclic aromatic hydrocarbons, and other pollutants measured by a mobile laboratory in Mexico City, Atmos. Chem. Phys., 5, 3377-3387, 2005, http://www.atmos-chem-phys.net/5/3377/2005/.

Johnson, K. S., Zuberi, B., Molina, L. T., Molina, M. J., Iedema,
M. J., Cowin, J. P., Gaspar, D. J., Wang, C., and Laskin, A.: Processing of soot in an urban environment: case study from the Mexico City Metropolitan Area, Atmos. Chem. Phys., 5, 30333043, 2005,

http://www.atmos-chem-phys.net/5/3033/2005/.

Johnson, K. S., de Foy, B., Zuberi, B., Molina, L. T., Molina, M. J., Xie, Y., Laskin, A., and Shutthanandan, V.: Aerosol composition and source apportionment in the Mexico City Metropolitan Area with PIXE/PESA/STIM and multivariate analysis, Atmos. Chem. Phys., 6, 4591-4600, 2006,

http://www.atmos-chem-phys.net/6/4591/2006/.

Jonsson, H. H., Wilson, J. C., Brock, C. A., Knollenberg, R. G., Newton, R., Dye, J. E., Baumgardner, D., Borrmann, S., Ferry, G. V., Pueschel, R., Woods, D. C., and Pitts, M. C.: Performance of a focused cavity aerosol spectrometer for measurements in the stratosphere of particle size in the $0.06-2.0-\mu \mathrm{m}$-diameter range, J. Atmos. Ocean. Tech., 12, 115-129, 1995.

Katrinak, K. A., Rez, P., and Buseck, P. R.: Structural variations in individual carbonaceous particles from an urban aerosol, Environ. Sci. Technol., 26, 1967-1976, 1992.

King, S. M., Rosenoern, T., Shilling, J. E., Chen, Q., and Martin, S. T.: Cloud condensation nucleus activity of secondary organic aerosol particles mixed with sulfate, Geophys. Res. Lett., 34, L24806, doi:10.1029/2007GL030390, 2007.

Kleinman, L. I., Springston, S. R., Daum, P. H., Lee, Y.-N., Nunnermacker, L. J., Senum, G. I., Wang, J., Weinstein-Lloyd, J., Alexander, M. L., Hubbe, J., Ortega, J., Canagaratna, M. R., and Jayne, J.: The time evolution of aerosol composition over the Mexico City plateau, Atmos. Chem. Phys., 8, 1559-1575, 2008, http://www.atmos-chem-phys.net/8/1559/2008/.

Kojima, T., Buseck, P. R., Wilson, J. C., Reeves, J. M., and Mahoney, M. J.: Aerosol particles from tropical convective systems: Cloud tops and cirrus anvils, J. Geophys. Res.-Atmos., 109, D12201, doi:10.1029/2003JD004504, 2004.

Kojima, T., Buseck, P. R., and Reeves, J. M.: Aerosol particles from tropical convective systems: 2. Cloud bases, J. Geophys. Res.Atmos., 110, D09203, doi:10.1029/2004JD005173, 2005.

Kojima, T., Buseck, P. R., Iwasaka, Y., Matsuki, A., and Trochkine, D.: Sulfate-coated dust particles in the free troposphere over Japan, Atmos. Res., 82, 698-708, 2006.

Köylü, Ü. Ö., Faeth, G. M., Farias, T. L., and Carvalho, M. G.: Fractal and projected structure properties of soot aggregates, Combust. Flame, 100, 621-633, 1995.

Kreidenweis, S. M., Remer, L. A., Bruintjes, R., and Dubovik, O.: Smoke aerosol from biomass burning in Mexico: Hygroscopic smoke optical model, J. Geophys. Res.-Atmos., 106, 4831-4844, 2001.

Li, J., Pósfai, M., Hobbs, P. V., and Buseck, P. R.: Individual aerosol particles from biomass burning in southern Africa: 2, Compositions and aging of inorganic particles, J. Geophys. Res.-Atmos., 108(D13), 8484, doi:10.1029/2002JD002310, 2003.

Liu, X. D., Van Espen, P., Adams, F., Cafmeyer, J., and Maenhaut, W.: Biomass burning in southern Africa: Individual particle characterization of atmospheric aerosols and savanna fire samples, J. Atmos. Chem., 36, 135-155, 2000.

Liu, L. and Mishchenko, M. I.: Effects of aggregation on scattering and radiative properties of soot aerosols, J. Geophys. Res.Atmos., 110, D11211, doi:10.1029/2004JD005649, 2005.

Lohmann, U., Broekhuizen, K., Leaitch, R., Shantz, N., and Abbatt, 
J.: How efficient is cloud droplet formation of organic aerosols?, Geophys. Res. Lett., 31, L05108, doi:10.1029/2003GL018999, 2004.

Mexico National Emissions Inventory 1999: http://www.epa.gov/ ttn/chief/net/mexico.html, last access: 2 July 2008, 2006.

Mishchenko, M. I., Liu, L., Travis, L. D., and Lacis, A. A.: Scattering and radiative properties of semi-external versus external mixtures of different aerosol types, J. Quant. Spectrosc. Ra., 88, 139-147, 2004.

Moffet, R. C., de Foy, B., Molina, L. T., Molina, M. J., and Prather, K. A.: Measurement of ambient aerosols in northern Mexico City by single particle mass spectrometry, Atmos. Chem. Phys., 8, 4499-4516, 2008, http://www.atmos-chem-phys.net/8/4499/2008/.

Mogo, S., Cachorro, V. E., and de Frutos, A. M.: Morphological, chemical and optical absorbing characterization of aerosols in the urban atmosphere of Valladolid, Atmos. Chem. Phys., 5, 27392748, 2005,

http://www.atmos-chem-phys.net/5/2739/2005/.

Molina, L. T. and Molina M. J. (Eds.): Air quality in the Mexico megacity, Kluwer academic publishers, The Netherlands, 2002.

Molina, L. T., Kolb, C. E., de Foy, B., Lamb, B. K., Brune, W. H., Jimenez, J. L., Ramos-Villegas, R., Sarmiento, J., ParamoFigueroa, V. H., Cardenas, B., Gutierrez-Avedoy, V., and Molina, M. J.: Air quality in North America's most populous city overview of the MCMA-2003 campaign, Atmos. Chem. Phys., 7, 2447-2473, 2007, http://www.atmos-chem-phys.net/7/2447/2007/.

Molina L. T., Madronich S., Gaffney J., and Singh H. B.: Overview of MILAGRO/INTEX-B campaign, IGACtivities Newsletter, 38, 2-15, 2008.

Molina, L. T., Madronich, S., Gaffney J. et al.: An overview of the MILAGRO 2006 Campaign: Mexico City emissions and its transport and transformation, Atmos. Chem. Phys. Discuss., in preparation, 2008.

Moya, M., Castro, T., Zepeda, M., and Baez, A.: Characterization of size-differentiated inorganic composition of aerosols in Mexico City, Atmos. Environ., 37, 3581-3591, 2003.

Murphy, D. M., Cziczo, D. J., Froyd, K. D., Hudson, P. K., Matthew, B. M., Middlebrook, A. M., Peltier, R. E., Sullivan, A., Thomson, D. S., and Weber, R. J.: Single-particle mass spectrometry of tropospheric aerosol particles, J. Geophys. Res.-Atmos., 111, D23S32, doi:10.1029/2006JD007340, 2006.

Myhre, G., Stordal, F., Restad, K., and Isaksen, I. S. A.: Estimation of the direct radiative forcing due to sulfate and soot aerosols, Tellus B, 50, 463-477, 1998.

Niemi, J. V., Saarikoski, S., Tervahattu, H., Mkel, T., Hillamo, R., Vehkamäki, H., Sogacheva, L., and Kulmala, M.: Changes in background aerosol composition in Finland during polluted and clean periods studied by TEM/EDX individual particle analysis, Atmos. Chem. Phys., 6, 5049-5066, 2006,

http://www.atmos-chem-phys.net/6/5049/2006/.

Okada, K., Ikegami, M., Zaizen, Y., Tsutsumi, Y., Makino, Y., Jensen, J. B., and Gras, J. L.: Soot particles in the free troposphere over Australia, Atmos. Environ., 39, 5079-5089, 2005.

Penner, J. E., Chuang, C. C., and Grant, K.: Climate forcing by carbonaceous and sulfate aerosols, Clim. Dynam., 14, 839-851, 1998.

Pósfai, M., Anderson, J. R., Buseck, P. R., and Sievering, H.:
Compositional variations of sea-salt-mode aerosol particles from the North Atlantic, J. Geophys. Res., 100(D11), 23 063-23 074, 1995.

Pósfai, M., Xu, H. F., Anderson, J. R., and Buseck, P. R.: Wet and dry sizes of atmospheric aerosol particles: An AFM-TEM study, Geophys. Res. Lett., 25, 1907-1910, 1998.

Pósfai, M., Anderson, J. R., Buseck, P. R., and Sievering, H.: Soot and sulfate aerosol particles in the remote marine troposphere, $\mathrm{J}$. Geophys. Res.-Atmos., 104, 21 685-21 693, 1999.

Pósfai, M., Simonics, R., Li, J., Hobbs, P. V., and Buseck, P. R.: Individual aerosol particles from biomass burning in southern Africa: 1. Compositions and size distributions of carbonaceous particles, J. Geophys. Res.-Atmos., 108(D13), 8483, doi:10.1029/2002JD002291, 2003.

Pósfai, M., Gelencsér, A., Simonics, R., Arató, K., Li, J., Hobbs, P. V., and Buseck, P. R.: Atmospheric tar balls: Particles from biomass and biofuel burning, J. Geophys. Res.-Atmos., 109, D06213, doi:10.1029/2003JD004169, 2004.

Querol, X., Pey, J., Minguilln, M. C., Prez, N., Alastuey, A., Viana, M., Moreno, T., Bernab, R. M., Blanco, S., Crdenas, B., Vega, E., Sosa, G., Escalona, S., Ruiz, H., and Artano, B.: PM speciation and sources in Mexico during the MILAGRO-2006 Campaign, Atmos. Chem. Phys., 8, 111-128, 2008, http://www.atmos-chem-phys.net/8/111/2008/.

Ramanathan, V., Crutzen, P. J., Kiehl, J. T., and Rosenfeld, D.: Atmosphere - Aerosols, climate, and the hydrological cycle, Science, 294, 2119-2124, 2001.

Ramanathan, V. and Carmichael, G.: Global and regional climate changes due to black carbon, Nature Geosci., 1, 221-227, 2008.

Saathoff, H., Moehler, O., Schurath, U., Kamm, S., Dippel, B., and Mihelcic, D.: The AIDA soot aerosol characterisation campaign 1999, J. Aerosol Sci., 34, 1277-1296, 2003.

Salcedo, D., Onasch, T. B., Dzepina, K., Canagaratna, M. R., Zhang, Q., Huffman, J. A., DeCarlo, P. F., Jayne, J. T., Mortimer, P., Worsnop, D. R., Kolb, C. E., Johnson, K. S., Zuberi, B., Marr, L. C., Volkamer, R., Molina, L. T., Molina, M. J., Cardenas, B., Bernabé, R. M., Márquez, C., Gaffney, J. S., Marley, N. A., Laskin, A., Shutthanandan, V., Xie, Y., Brune, W., Lesher, R., Shirley, T., and Jimenez, J. L.: Characterization of ambient aerosols in Mexico City during the MCMA-2003 campaign with Aerosol Mass Spectrometry: results from the CENICA Supersite, Atmos. Chem. Phys., 6, 925-946, 2006,

http://www.atmos-chem-phys.net/6/925/2006/.

Schwarz, J. P., Spackman, J. R., Fahey, D. W., Gao, R. S., Lohmann, U., Stier, P., Watts, L. A., Thomson, D. S., Lack, D. A., Pfister, L. , Mahoney, M. J., Baumgardner, D., Wilson, J. C., and Reeves, J. M.: Coatings and their enhancement of black carbon light absorption in the tropical atmosphere, J. Geophys. Res., 113, D03203, doi:10.1029/2007JD009042, 2008.

Seinfeld, J. H. and Pandis, S. N.: Atmospheric chemistry and physics, 2nd edition, John Wiley \& Sons Inc., New Jersey, 2006.

Seinfeld, J. H. and Pankow, J. F.: Organic atmospheric particulate material, Annu. Rev. Phys. Chem. 54, 121-140, 2003.

Smith, J. N., Dunn, M. J., VanReken, T. M., Iida, K., Stolzenburg, M. R., McMurry, P. H., and Huey, L. G.: Chemical composition of atmospheric nanoparticles formed from nucleation in Tecamac, Mexico: Evidence for an important role for organic species in nanoparticle growth, Geophys. Res. Lett., 35, L04808, doi:10.1029/2007GL032523, 2008. 
Stier, P., Seinfeld, J. H., Kinne, S., and Boucher, O.: Aerosol absorption and radiative forcing, Atmos. Chem. Phys., 7, 52375261, 2007, http://www.atmos-chem-phys.net/7/5237/2007/.

Stone, E. A., Snyder, D. C., Sheesley, R. J., Sullivan, A. P., Weber, R. J., and Schauer, J. J.: Source apportionment of fine organic aerosol in Mexico City during the MILAGRO experiment 2006, Atmos. Chem. Phys., 8, 1249-1259, 2008, http://www.atmos-chem-phys.net/8/1249/2008/.

Takahama, S., Gilardoni, S., Russell, L. M., and Kilcoyne, A. L. D.: Classification of multiple types of organic carbon composition in atmospheric particles by scanning transmission X-ray microscopy analysis, Atmos. Environ., 41, 9435-9451, 2007.

Takemura, T., Nozawa, T., Emori, S., Nakajima, T. Y., and Nakajima, T.: Simulation of climate response to aerosol direct and indirect effects with aerosol transport-radiation model, J. Geophys. Res.-Atmos., 110, D02202, doi:10.1029/2004JD005029, 2005.

Utsunomiya, S., Jensen, K. A., Keeler, G. J., and Ewing, R. C.: Direct identification of trace metals in fine and ultrafine particles in the Detroit urban atmosphere, Environ. Sci. Technol., 38, 22892297, 2004.

van Poppel, L. H., Friedrich, H., Spinsby, J., Chung, S. H., Seinfeld, J. H., and Buseck, P. R.: Electron tomography of nanoparticle clusters: Implications for atmospheric lifetimes and radiative forcing of soot, Geophys. Res. Lett., 32, L24811, doi:10.1029/2005GL024461, 2005.
Yamato, M. and Ono, A.: Chemical and physical properties of stratospheric aerosol particles in the vicinity of tropopause folding, J. Meteorol. Soc. Jpn., 67, 147-166, 1989.

Yamato, M. and Tanaka, H.: Aircraft observations of aerosols in the free marine troposphere over the North Pacific Ocean: Particle chemistry in relation to air mass origin, J. Geophys. Res., 99(D3), 5353-5378, 1994.

Yokelson, R. J., Urbanski, S. P., Atlas, E. L., Toohey, D. W., Alvarado, E. C., Crounse, J. D., Wennberg, P. O., Fisher, M. E., Wold, C. E., Campos, T. L., Adachi, K., Buseck, P. R., and Hao, W. M.: Emissions from forest fires near Mexico City, Atmos. Chem. Phys., 7, 5569-5584, 2007, http://www.atmos-chem-phys.net/7/5569/2007/.

Zavala, M., Herndon, S. C., Slott, R. S., Dunlea, E. J., Marr, L. C., Shorter, J. H., Zahniser, M., Knighton, W. B., Rogers, T. M., Kolb, C. E., Molina, L. T., and Molina, M. J.: Characterization of on-road vehicle emissions in the Mexico City Metropolitan Area using a mobile laboratory in chase and fleet average measurement modes during the MCMA-2003 field campaign, Atmos. Chem. Phys., 6, 5129-5142, 2006,

http://www.atmos-chem-phys.net/6/5129/2006/. 